\title{
LA GARANTÍA DE OBJETIVIDAD DEL FISCAL
}

\author{
Carlos Manuel Romero Berdullas \\ Doctor en Derecho Penal y Ciencias Penales, \\ Universidad del Salvador \\ Investigador independiente \\ Contacto: romeroberdullascm@yahoo.com.ar
}

Recibido: 10 de marzo de 2021

Aprobado: 30 de abril de 2021

Para citar este artículo:

Romero Berdullas, C. M. (2021). "La garantía de objetividad del fiscal”. Prudentia Iuris, N. 92, pp. 33-63

DOI: https://doi.org/10.46553/prudentia.92.2021.pp.33-63

\begin{abstract}
Resumen: La "objetividad del fiscal" no solo constituye una garantía de los imputados ante persecuciones signadas por la arbitrariedad, sino también un reaseguro de las víctimas (comunidad política y particular) de los hechos penales, de que dado ese mal gravísimo llamado "delito", la lesión al orden de justicia será restaurada en procura de las justas exigencias del bien común. Los conceptos indeterminados implícitos en la insignificancia procesal, la orfandad de controles republicanos y la posible defectuosidad del hombre son algunos de los riesgos expuestos en este trabajo, que interpelan a asegurar esa "garantía de objetividad" en el fiscal, ya sea disipando dudas susceptibles de anidarse en la sociedad sobre la credibilidad del sistema de justicia ante designaciones especiales; como así también, librando a los acusadores públicos de potenciales presiones, influencias e interferencias en su autonomía funcional, pues éstas podrían traducirse en desmedro o privilegio de un caso particular.
\end{abstract}

Palabras clave: Objetividad, Fiscal, Garantía, Subjetividad, Oportunidad, Arbitrariedad. 


\title{
The Prosecutor Guarantee of Objectivity
}

\begin{abstract}
The "objectivity of the prosecutor" not only constitutes a guarantee for the accused in the face of arbitrary prosecutions, but also a reassurance of the victims (political and private community) of the criminal acts, that given this very serious evil called "crime", the injury to the order of justice will be restored in pursuit of the just demands of the common good. The indeterminate concepts implicit in the procedural insignificance, the orphanhood of republican controls and the possible defectiveness of the man are some of the risks exposed in this work, which challenge to ensure that "guarantee of objectivity" in the prosecutor, either by dispelling doubts that may arise nest in society on the credibility of the justice system before special appointments; as well as, freeing public prosecutors from potential pressures, influences and interferences in their functional autonomy, as these could translate into detriment or privilege of a particular case.
\end{abstract}

Keywords: Objectivity, Prosecutor, Guarantee, Subjectivity, Discretionary power, Arbitrariness.

\section{La garanzia di obiettività del pubblico ministero}

Sommario: L "obiettività del pubblico ministero" costituisce non solo una garanzia per l'imputato di fronte a procedimenti arbitrari, ma anche una rassicurazione delle vittime (comunità politica e privata) degli atti criminali, che dato questo gravissimo male chiamato "reato", la lesione dell'ordine della giustizia sarà ripristinata nel perseguimento delle giuste esigenze del bene comune. I concetti indeterminati impliciti nell'insignificanza procedurale, nell'orfanità dei controlli repubblicani e nella possibile difettosità dell'uomo sono alcuni dei rischi esposti in quest'opera, che sfida a garantire quella "garanzia di obiettività" nel pubblico ministero, sia fugando dubbi che può sorgere nido nella società sulla credibilità del sistema giudiziario prima di nomine speciali; nonché, liberando i pubblici ministeri da potenziali pressioni, influenze e interferenze nella loro autonomia funzionale, in quanto queste potrebbero tradursi in pregiudizio o privilegio di un caso particolare. 
Parole chiave: Obiettività, Procuratore, Garanzia, Soggettività, Potere discrezionale, Arbitrarietà.

\section{Introducción}

Después de sortear no pocas vicisitudes a lo largo de la historia, hoy ese Ministerio Público Fiscal ${ }^{1}$, que fuera otrora caracterizado como un "adolescente" 0 "fruto tardío"3 y habría emergido de las "cenizas de la edad media"4, prosigue buscando esa mayoría de edad tan anhelada.

Si bien el advenimiento del proceso acusatorio y diferentes reformas legislativas conceden a los fiscales un protagonismo más acorde a su identidad, ciertamente la introducción de la insignificancia procesal o el foráneo principio de oportunidad abren desafíos antes inimaginables, para todos aquellos que aspiran a garantizar una actuación de los acusadores públicos no permeable a la arbitrariedad, ni a la vacuidad de contrapesos.

En línea con ello, se advierte la importancia de delimitar el alcance del principio de objetividad, que según diversas normas debe signar el desempeño de los titulares de la acción penal pública. Pues esta es una ocasión propicia para preguntarse, si así, como la Constitución Nacional consagra una "garantía del juez natural", si no es una fiel expresión del ideario constituyente, una "garantía de objetividad del fiscal" que debería asegurarse no solo en favor del imputado, sino también de las víctimas del delito.

Por tanto, en traza de alcanzar el culmen propuesto, primero analizaremos la regulación del deber de objetividad, peldaño que será complementado con una aproximación conceptual a lo objetivo, la cual procurará llegar a la verdad y esencia de las cosas.

Luego, precisada la relevancia de la objetividad como actitud cognoscitiva y ética del fiscal en el proceso, determinaremos si ese "ser objetivo" se traduce en un desempeño imparcial o presenta una nota diferencial en este sujeto procesal; tras lo cual, discurriremos acerca de la necesidad de garantizar que, dentro de un horizonte procesal abierto a los peligros implícitos en los conceptos indeterminados de la insignificancia procesal u oportunidad libre, el proceder del acusador público no se pierda en el subjetivismo.

1 En adelante, MPF.

2 Maier, J. B. J. (2003). “El Ministerio Público: ¿un adolescente?”. En AA. VV., El Ministerio Público en el Proceso Penal. $1^{\mathrm{a}}$ ed. Buenos Aires. Ad-Hoc.

3 Roxin, C. (2003). "Posición Jurídica y tareas futuras del Ministerio Público". En AA. VV., El Ministerio Público... Ob. cit.

4 Vélez Mariconde, A. (1969). Derecho Procesal Penal. T. I. $2^{\text {a }}$ ed. Buenos Aires. Lerner, 241. 
De modo tal, que una vez alcanzada esta perspectiva moveremos la razón para reflexionar sobre el valor de idear diferentes mecanismos destinados a eliminar cualquier viso de asignación arbitraria de los fiscales para investigar delitos con posterioridad a los hechos de los procesos. Pues las novedades legislativas plantean nuevos retos a los filósofos del Derecho Penal o los arquitectos del sistema de justicia, quienes si de verdad, en este caso, añoran garantizar un obrar de los acusadores públicos ajustado a las justas exigencias del bien común político, ineluctablemente deben confrontar estas innovaciones procesales con una "objetividad fiscal", que se expresa en una actitud realista tendente a concretar la justicia con el ser.

\section{El deber de objetividad}

\section{2.a. Regulación normativa}

Variadas proyecciones del deber de objetividad se pueden encontrar en diferentes Códigos Procesales Penales de cuño acusatorio y disímiles normas orgánicas del MPF.

Así pues, este imperativo de objetividad se expresa a modo de ejemplo en el Código Procesal Penal Federal ${ }^{5}$-aprobado el 7 de febrero de 2019 por Ley $\mathrm{N}^{\circ}$ 27.063-, cuando se precisa que el representante del MPF debe:

a) inhibirse y puede recusarse en caso de que su objetivo desempeño se vea afectado por algún motivo serio y razonable (art. 89, CPPF);

b actuar bajo el principio de objetividad y buena fe en la recolección de elementos de prueba (art. 128, CPPF) ${ }^{6}$;

c) conducir la investigación preparatoria con un criterio objetivo (art. 196, CPPF); y

d) recoger con celeridad los elementos de cargo y descargo que sean de utilidad para indagar la verdad (art. 196, CPPF).

Inclusive, el mismo cuerpo procesal añade que el fiscal posee la facultad derivada de recurrir en favor del imputado (art. 297, CPPF), caso en el cual la resolución impugnada no podría modificarse en desmedro del acusado, dada la doctrina de la "reformatio in pejus".

5 En adelante, CPPF.

6 Una norma análoga contiene el Código Procesal Penal de la provincia de Salta (art. 284, Ley $\mathrm{N}^{\circ} 7.690$ ). 
Por su parte, la Ley Orgánica No 27.148 -sancionada el 10 de junio de 2015- delimita al principio funcional de objetividad como uno de los vectores de la actuación del MPF de la Nación, que se traduciría en "requerir la aplicación justa de la ley, procurando el resguardo equilibrado de todos los valores y principios jurídicos vigentes", de consuno al ejercicio racional/ponderado del poder penal del Estado (cfr. art. $9^{\circ}$.d de la ley citada).

Análogas prescripciones sobre el criterio de objetividad se observan en la Ley Orgánica del Ministerio Público de la Ciudad Autónoma de Buenos Aires ${ }^{7}$, en tanto el M. debe ejercer "sus funciones específicas de modo objetivo con estricta observancia de la legalidad general [...]" (art. $2^{\circ}$, Ley $\mathrm{N}^{\mathrm{o}}$ 1.903); y en el Código Procesal Penal local ${ }^{8}$, pues allí se establece:

a) "En el ejercicio de su función, el Ministerio Público Fiscal adecuará sus actos a un criterio objetivo" e "investigará las circunstancias que permitan comprobar la acusación y las que sirvan para eximir de responsabilidad al/la imputado/a y formular los requerimientos e instancias conforme a ese criterio de objetividad" (art. $6^{\circ 9}$, CPPCABA);

b) "El/la fiscal deberá investigar todos los hechos y circunstancias pertinentes y útiles a que se hubiere referido el/la imputado/a en sus declaraciones o en sus escritos de descargo, que objetivamente pudieran incidir en su situación procesal y/o la remisión o no de las actuaciones a juicio" (art. 179, CPPCABA);

c) "El archivo de las denuncias y de las actuaciones de prevención procederá cuando: [...] [d]e la objetiva valoración de los elementos acompañados surja claramente que no hay posibilidad de promover la investigación o individualizar a los autores del hecho" (art. 211, CPPCABA); y

d) "Además de los casos especialmente previstos, el/la fiscal podrá recurrir siempre a fin de controlar la legalidad del procedimiento, incluso en favor del/la imputado/a" (art. 280, CPPCABA).

Por lo demás, diversas provincias de la República Argentina también contienen normas que definen en su ámbito de actuación al llamado principio de objetividad, tal cual se puede comprobar a partir de la lectura de los Códigos Procesales Penales de la provincia de Buenos Aires (arts. 56 y 323,

7 En adelante, MP.

8 En adelante, CPPCABA.

9 Según numeración suministrada en Anexo I de la Ley local No 6347, a través de la cual se aprobó la $3^{\mathrm{a}}$ actualización del Digesto Jurídico de la CABA, que contiene las normas consolidadas al 31 de agosto de 2020 . 
Ley $\mathrm{N}^{\mathrm{o}}$ 11.922), Salta (arts. 77 y 284, Ley $\mathrm{N}^{\mathrm{o}}$ 7.690), San Juan (art. 93, Ley $\mathrm{N}^{\mathrm{o}}$ 7.398), La Rioja (art. 204 bis, inc. $5^{\circ}$, Ley $\mathrm{N}^{\mathrm{o}} 1.574$ ), Mendoza (art. 352, según Ley $\mathrm{N}^{\circ}$ 6.730), Tucumán (art. 359, Ley $\mathrm{N}^{\circ}$ 6.203) y Córdoba (art. 350, Ley $\mathrm{N}^{\circ} 8.123$ ).

\section{2.b. Aproximación a su concepto}

Corroborada la recepción del deber de objetividad en diferentes moldes procesales, es tiempo de aproximarnos a una conceptualización. Por tanto, en traza de alcanzar este cometido nada parece más conveniente que acudir, primero, al Diccionario de la Real Academia Española, donde se define a la objetividad como a la "cualidad de objetivo"10.

Entre las disímiles acepciones suministradas sobre la palabra objetivo/a, que resultan susceptibles de vincularse con el principio aquí analizado, interesa rescatar las siguientes:

"1. adj. Perteneciente o relativo al objeto en sí mismo, con independencia de la propia manera de pensar o de sentir.

2. adj. Desinteresado, desapasionado.

3. adj. Fil. Que existe realmente, fuera del sujeto que lo conoce"11.

A su vez, el Diccionario Panhispánico del Español Jurídico define la palabra objetividad como aquel "[...] [p]rincipio complementario al de imparcialidad que exige actuar atendiendo a criterios objetivos, es decir, relacionados con el objeto sometido a consideración y nunca con los sujetos interesados ni con el sentir de quien actúa"12. En tanto al precisar una definición de objetivo / a, alude a aquello "[p]erteneciente o relativo al objeto con independencia de las circunstancias personales (tanto las del sujeto interviniente como las del sujeto interesado)"13.

10 Real Academia Española (RAE). Diccionario de la Real Academia Española (disponible en https://dle.rae.es/objetivo, fecha de consulta: 10-12-2020). Ed. del Tricentenario, actualización 2020.

11 Real Academia Española (RAE). Diccionario de la Real Academia Española (disponible en https://dle.rae.es/objetivo, fecha de consulta: 9-12-2020). Ed. del Tricentenario, actualización 2020.

12 Real Academia Española (RAE) y Consejo General del Poder Judicial (CGPJ). Diccionario Panhispánico del Español Jurídico (disponible en https://dpej.rae.es/lema/objetividad, fecha de consulta: 9-12-2020).

13 Real Academia Española (RAE) y Consejo General del Poder Judicial (CGPJ). Diccionario Panhispánico del Español Jurídico (disponible en https://dpej.rae.es/lema/objetivo1-va, fecha de consulta: 9-12-2020). 
Hecha esta concisa exploración tendente a aproximarnos a la noción del término objetividad, no es en vano abrevar en el fecundo magisterio de Josef Pieper, quien explica que la palabra alemana sachlichkeit es pasible de traducirse al castellano como objetividad; y tiene en su raíz el vocablo Sache, cuyo significado es "cosa" $(\text { res })^{14}$. De ahí que, según su buen entender, de esta forma resulta más explícita su vinculación con la realidad, en tanto la objetividad es "la actitud de quien busca adecuarse a lo que las cosas son"; y por eso alude a una "justicia con el ser" 15.

De este modo, podemos confirmar el sentido prístino de la palabra objetividad y objeto (del lat. ob-iectum), que en el prefijo $o b^{16}$ denota esa actitud de hallarse "en contra" o "delante de" algo no meramente pensado (ens rationis), sino real. Por consiguiente, se puede comprender, así, la íntima imbricación entre la objetividad y "lo real", o sea, aquello que se encuentra "en frente" al conocimiento sensitivo e intelectual con independencia del pensamiento.

Y esto ese esencial comprenderlo, en la medida en que tal cual se adelantara en clave con Pieper: "[...] los deberes éticos se fundan justamente en la realidad, es decir, en el ser de las cosas. Por ello es imprescindible conocer la verdad de las cosas, en donde se manifiesta lo que 'es'. Esto es así, dado que, para hacer el bien, una premisa fundamental es conocer verdaderamente la realidad. Contrario sensu, si se rechaza lo real y actúa con una mirada no adecuada a lo que las cosas son, simplemente por una contradicción óntico-lógica se hará el mal. Y aquí vale hacer una observación esencial, la realidad es independiente de nuestra voluntad, intención, valores, ideologías, pensamientos o mayorías. [...] y [p]ara ser justo, necesariamente debemos relacionarnos con lo real en forma objetiva, de lo contrario no podremos adecuar nuestro obrar a lo que las cosas son"17.

Es que como explica el preclaro Pieper, "ser bueno quiere decir hacer justicia al ser objetivo"; pues "bueno es lo que corresponde a la cosa"; y "el bien es lo conforme a la realidad objetiva"18. Y por ello es que "la justicia con el ser" se concretará, en tanto el hombre o el fiscal enseñen esa docilidad necesaria para dejar determinarse objetivamente por la realidad (docilitas) y no procuren co-determinar el conocimiento "queriendo que algo sea, no

14 Cfr. Pieper, J. (2009). La realidad y el Bien. La verdad de las cosas. Buenos Aires. Librería Córdoba, 14.

15 Ídem.

16 El prefijo ob. se asimila a op. [cfr. Corominas, J. (1981). Diccionario Crítico Etimológico Castellano e Hispánico. T. IV. Madrid. Gredos, 287].

17 Romero Berdullas, C. M. (diciembre de 2018). "Mitos y realidades del proceso acusatorio". Prudentia Iuris n ${ }^{\circ}$ 86. Buenos Aires. Educa, 141.

18 Pieper, J. Ob. cit., 11. 
sea o sea otra cosa diferente de lo que es, echando así a perder cualquier pretensión de obrar prudente, justo y bueno"19.

Esto enseña, entonces, la ineludible relación entre la objetividad y la actitud que el sujeto (en nuestro caso, el fiscal) adopte ante la realidad. Pues únicamente podrá darse la objetividad, en tanto se asuma una actitud realista, esto es, aquella que "admite, como principio, que el ser (la realidad) determina el pensamiento, tanto en su acto (que es también algo real) como en su contenido objetivo, cuyo valor de verdad se juzga por comparación -conformidad- con el ser"20. En cambio, no se podrá llegar al objeto, ni ser objetivo, si se toma como faro del obrar una actitud idealista y deconstructiva de lo real, o sea, aquella que visualiza al pensamiento o la conciencia como constitutivos de la realidad (es decir, del ser) ${ }^{21}$.

Es importante destacar esto último, pues si bien este idealismo filosófico -iniciado con Descartes, proseguido con Kant y continuado con Hegeldel cual emana el materialismo marxista ${ }^{22}$ traduce un planteo ajeno a una medida de razonabilidad y divorciado de lo real, ciertamente ha tenido su eco a lo largo de la historia, tal como se puede comprobar en la actualidad con su proyección en diferentes ideologías tendentes a deconstruir la realidad, que inexorablemente conducen al primado de la arbitrariedad.

Concretamente, enseña Sacheri que para el "idealismo es la conciencia del sujeto [...] cuando conoce el que fabrica, produce las cosas"23. Puede verse, entonces, aquí una actitud distante de "ver las cosas tal cual las cosas con" ${ }^{24}$, pues "en el acto de conocer, el sujeto o la conciencia del sujeto crea el objeto, lo produce, lo hace existir [...]"25.

Se evidencia cómo esta actitud no condice con la objetividad en el conocer del ser humano -y por añadidura tampoco con la propia del fiscal-, pues la captación intencional de los objetos únicamente se concretará, si y solo si, se parte de una intención del conocimiento por el cual se tiende al objeto, en traza de captar lo que éste es.

De hecho, el conocimiento adquirido por el fiscal será verdadero, en tanto la hipótesis ideada por él sobre "la realidad investigada" coincida con lo que "la realidad es". Es decir, si su hipótesis del caso reproduce fidedigna-

19 Romero Berdullas, C. M., "Mitos y...". Ob. cit., 141.

20 Lamas, F. A. (2013). El hombre y su conducta. Buenos Aires. Instituto de Estudios Filosóficos "Santo Tomás de Aquino", 72.

21 Cfr. lo enseñado en Lamas, F. A. Ob. cit., 72.

22 Sacheri, C. (2016). Filosofía e Historia de las ideas filosóficas. Mendoza. Escipión, 43-44.

23 Sacheri, C. Ob. cit., 43.

24 Ídem.

25 Ídem. 
mente la realidad objetiva habrá llegado a la "verdad de las cosas mismas" (verdad ontológica) y ajustado su inteligencia a lo que "es" (verdad lógica). Simplificando, si el "ser" determina el "pensamiento" del fiscal se habrá dado la objetividad; mientras que si el "pensamiento" del titular de la acción penal determina al "ser" no se concretará una captación o aprehensión de la realidad ${ }^{26}$.

Lo hasta aquí escrito denota que este principio de objetividad se afinca en la "necesidad de alcanzar la verdad. Una verdad a secas, que no es real ni formal, pues la verdad sobre lo acontecido es una. Por lo que es redundante aludir a una verdad real; e incorrecto referirse a una verdad procesal divergente de la real, pues si difiere de lo que las cosas son, en definitiva, no es verdad"27.

Aquí basta añadir que la afirmación del principio, deber o criterio de objetividad carecería de sentido si se negara la existencia de verdades objetivas (relativismo) o se rechazara la viabilidad de conocer algo con certeza (escepticismo).

No obstante, con esta rubricación del principio de objetivad no se desconocen las posibles limitaciones o dificultades cognoscitivas en la actividad del fiscal, pues como es sabido, en el proceso únicamente podemos alcanzar una certeza ajustada a la materia sobre la cual discurrimos ${ }^{28}$, es decir, la de los asuntos humanos. Por ende, al recaer en la dialéctica el razonamiento sobre cosas probables (contrario sensu a la metafísica o las matemáticas), el grado de certeza al cual podrá acceder el fiscal es el propio del ámbito de la deliberación de los asuntos morales o jurídicos; y, en consecuencia, solo comprenderá el campo de las conclusiones plausibles, contingentes o no necesarias.

En suma, a partir de su investigación, el fiscal podrá llegar a una certeza práctica, probable y moral sobre el sustrato fáctico del caso en base a una ponderación objetiva, que si bien no es absoluta, será suficiente para: a) archivar la causa si el hecho resultare atípico o se encontrara prescripto, el autor fuera inimputable, se configurara alguna causa de justificación o exención de pena, no surgiera posibilidad alguna de promover la inves-

26 Huelga destacar, que la verdad no se construye a través del proceso. Stricto sensu, la verdad puede reconocerse o no mediante el proceso, pero no construirse por su intermedio, en tanto es independiente del mismo. Por tanto, no es atinado aludir a la "necesidad de fundar los dictámenes y la actividad de la fiscalía en criterios objetivos respecto de la construcción de la verdad acerca del objeto procesal (el hecho punible concreto que se intenta conocer en el procedimiento)", tal cual se enseña en Maier, J. B. J. (2011). Derecho Procesal Penal, II. Parte General, Sujetos Procesales. $1^{\mathrm{a}}$ ed., $2^{\mathrm{a}}$ reimp. Buenos Aires. Editores del Puerto, 322-323.

27 Romero Berdullas, C. M. (diciembre de 2018). "Mitos y...”. Ob. cit., 142.

28 Cfr. lo enseñado en Aristóteles (2011). Ética Nicomáquea. Madrid. Gredos, L. I, cap. III, 1094b, 23 ss., 15, donde se explica la necesidad de no afanarse por alcanzar otra precisión en cada género de problemas, sino la que consiente a la naturaleza del asunto. 
tigación o individualizar a los autores del hecho o se aplicara otra clase de respuesta (ej.: suspensión del proceso a prueba); o b) requerir el juicio público del imputado para proceder a su acusación, de contar con un plexo probatorio de entidad sobre la existencia del delito, su autoría, la culpabilidad interna del presunto autor y su responsabilidad.

\section{2.c. La objetividad como actitud cognoscitiva y ética del fiscal}

A tenor de lo hasta aquí desarrollado, puede observarse que la objetividad del fiscal es un reaseguro ante la potencial arbitrariedad, tanto para el imputado como para las víctimas (comunidad política o particular) de los delitos, en tanto de esta manera el contenido del conocimiento viene determinado por las cosas; y no por el voluntarismo del titular del ejercicio de la acción penal, quien impulsado por su subjetividad fácilmente podría trocar a cualquier "inocente" en "presunto culpable" o a la inversa, cubrir a todo delincuente bajo el velo de la impunidad (por ej.: archivando el expediente por aplicación del llamado principio de oportunidad), si no ajustara su actuación a criterios objetivos, ya sea no investigando circunstancias incriminatorias o eximentes de responsabilidad; o no adecuando sus requerimientos y decisiones a la realidad.

En este sentido, la objetividad y la verdad constituyen una garantía de las víctimas, dado que posibilitan la concreción de la manda de dar a quien delinque su pena y no al inocente (acto de justicia ordenado al bien común), pero también es garantía de los imputados, frente a persecuciones signadas por la arbitrariedad.

De modo que en el campo cognoscitivo la objetividad como actitud del fiscal implica un desistimiento del representante del MPF a co-determinar el contenido de su conocimiento sobre la causa, cuya investigación se halla a su cargo. En efecto, esta actitud caracterizada por Pieper como "una ascesis del conocer" es presupuesto; y a la par, primera garantía de un conocimiento auténtico ${ }^{29}$.

Ahora bien, esa objetividad como actitud cognoscitiva del fiscal, que se adecúa a las circunstancias de cada caso, inexorablemente tiene proyección en el campo ético, en tanto el dictamen de la razón práctica y la acción del acusador deben ser determinados por la realidad objetiva de las cosas e impedir la influencia subjetiva ${ }^{30}$.

29 Piper, J. Ob. cit., 31-33 y 64.

30 Cfr. la fecunda lección de Piper, J. Ob. cit., 31-33 y 64-67. 
De ahí que la objetividad del fiscal no solo es una actitud cognoscitiva, sino también ética. Una actitud ética esencial, que no debe confundirse con neutralidad o pasividad, pues el acto de "tender hacia", al cual aquí aludimos, se traduce en el compromiso por aferrar a la realidad. Por ello es que, según Pieper: “'Objetividad' y apasionamiento se llevan bien entre sí”31.

\section{2.d. Alcance de una actuación fiscal objetiva}

Podemos alcanzar una primera aproximación a la objetividad aludida, cuando definimos ese criterio objetivo del fiscal por aquella búsqueda emprendida con el propósito de ajustar su desempeño a lo que las cosas son. Sobre este punto vale resaltar que la medida de lo real es presupuesto de una actividad fiscal orientada a realizar la justicia entre los hombres. Pues de no ponderar el fiscal a las cosas como único vector de datos e influenciar subjetivamente sobre su contenido, irremediablemente no actuará con fidelidad hacia lo denotado por la realidad; y, en consecuencia, su accionar no será justo ${ }^{32}$.

Si bien en una matriz procesal acusatoria el fiscal posee un interés persecutorio con proyecciones en un proceso irradiado por la competencia comunicativa, donde el posicionamiento estratégico cobra gran valor en los casos concretos o en vistas al cumplimiento de objetivos institucionales socialmente cuantificables, per se no se observa contradicción alguna entre la condición de parte del acusador y la objetividad que debe guiar su actividad en defensa de la legalidad e intereses generales de la sociedad.

Más aún, la misión de los fiscales de custodiar la legalidad y la Constitución Política de la Nación se encuentra indisolublemente enhebrada a la meta de procurar una justicia acorde a la realidad. Es que esta objetividad remite a la necesidad de indagar la verdad si uno se propone ser justo con la víctima comunidad política, las víctimas particulares (si las hubiere) ${ }^{33} \mathrm{y}$ los imputados.

31 Piper, J. Ob. cit., 66.

32 Romero Berdullas, C. M. (2015). “\#Proceso Acusatorio: ¿Hashtag Constitucional?”. Forum 3. Buenos Aires. Educa, pp. 102-103.

33 La fórmula "si las hubiere" no es antojadiza, pues responde a que podría haber delito sin víctima particular. En cambio, lo que siempre sí se encuentra presente ante la comisión de un delito es la lesión a la víctima comunidad política. Como explica Jiménez de Asúa, la comunidad política o Estado siempre es titular del interés ofendido por el delito, aunque puede resultar sujeto pasivo inmediato o mediato. Por cierto, ante la realización de un delito, el Estado puede ser víctima o sujeto pasivo inmediato (por ej.: frente a conductas como la traición, la rebelión, la sedición u otros actos disvaliosos que comprometen la paz); o víctima o sujeto pasivo mediato (por ej.: cuando el delito lesiona un interés propio particular, como acontece en 
De lo contrario, si el fiscal se disociara de la realidad se incurriría en:

a) un desacertado reduccionismo, puesto que se restringiría la objetividad a reglas de fair play, lealtad y buena fe, consistentes en dar a conocer a la defensa toda la prueba útil para resistir la acusación $34 ;$ y

b) una viciada premisa de sus decisiones estratégicas, dado que cabría la posibilidad de convertirse en un acusador ciego al co-determinar subjetivamente el contenido de los hechos pesquisados, validar infundadamente el impulso de acciones penales o acusar sin el debido sustento probatorio ${ }^{35}$.

Por consiguiente, el fiscal debe ejercer la acción pública y practicar diligencias con la finalidad de determinar la existencia del hecho delictivo, pero al mismo tiempo debe adecuar sus actos a un criterio objetivo (art. 196, CPPF). Es decir, debe recoger con celeridad los elementos de cargo o descargo que permitan averiguar la verdad, con el objeto de elaborar sus requerimientos en consonancia con estas pautas objetivas.

Tal como lo explica Gössel, "el Ministerio Fiscal ha de procurar que la conducta del sospechoso sea examinada [...] con estricta observancia de los principios del Derecho Penal. Y [...] ha de instar el sobreseimiento de la causa cuando presuma que la persona acusada no ha de ser condenada, por la ausencia de responsabilidad criminal, liberándola de la persecución penal"36.

La verdadera función del fiscal, según el doctrinario citado, "consiste en examinar objetiva y críticamente los hechos averiguados en el procedimiento preliminar, para discernir si existe la sospecha de un comportamiento punible, y, por ello, la probabilidad de un fallo penal de culpabilidad, o la ausencia de indicios de criminalidad, y, en su virtud, la procedencia del sobreseimiento de la causa" ${ }^{37}$.

En cualquier caso, ya desde una etapa precoz de la investigación, el sustrato de lo investigado debe hallarse definido por lo fáctico, mas no por la voluntad del fiscal, quien no puede erigir la visión de la realidad sobre su voluntarismo. Los hechos representados por intermedio de pruebas indagadas estratégicamente y con objetividad son los que delimitarán si el fiscal

\footnotetext{
el caso del homicidio, aborto u homicidio prenatal, el robo, etc.). [Jiménez de Asúa, L. (1965). Tratado de Derecho Penal, El delito. T. III. $3^{\text {a }}$ ed. act. Buenos Aires. Losada, nº 979, 92-93].

34 Romero Berdullas, C. M. (2015), “\#Proceso Acusatorio...”. Ob. cit., 103.

35 Ídem.

36 Gössel, K. H. (2007). El Derecho Procesal Penal en el Estado de Derecho. Obras Completas. T. I. Buenos Aires. Rubinzal Culzoni, 48.

37 Ídem.
} 
debe promover la realización del juicio, desecharlo; o arribar a otra clase de respuesta.

En efecto, el desempeño del fiscal debe hallarse guiado por "la medida de lo real"38 y el respeto irrestricto de las garantías individuales reconocidas constitucionalmente en un juicio justo ${ }^{39}$. De ahí que, al emitir su alegato final, el fiscal debería solicitar la absolución del acusado si entendiese que es inocente o el hecho no ha sido probado durante la etapa de juicio ${ }^{40}$.

\section{2.e. Objetividad e imparcialidad}

Según el Dr. Don Julio B. J. Maier, el principio de legalidad procesal conduciría a "la necesidad de fundar los dictámenes y la actividad de la fiscalía en criterios objetivos respecto de la construcción de la verdad acerca del objeto procesal (el hecho punible concreto que se intenta conocer en el procedimiento)"41. Esgrime, entonces, que "se trata del llamado principio de objetividad, que rige no solo la actividad de los jueces, sino también la tarea del Ministerio Público, entre nosotros" 42 . Por consiguiente, a su entender, tal "afirmación implica, necesariamente, el rechazo de toda idea relativa al desarrollo de un interés subjetivo o utilidad política -no contenido en la ley- como su misión; y tal implicación desemboca, precisamente, en la advertencia de que la construcción de la verdad por los jueces, para fundar sus decisiones, es gobernada por las mismas reglas que rigen para la fiscalía" 43 .

38 Romero Berdullas, C. M. (2015). “\#Proceso Acusatorio...”. Ob. cit., 103.

39 Cfr. párrafos $1^{\circ}$ y $3^{\circ}$ de "Normas de Responsabilidad Profesional y Establecimiento de Deberes y Derechos de Fiscales" (1999); par. 13.b) de "Directrices sobre la función de los fiscales", aprobadas en el $8^{\circ}$ Congreso de las Naciones Unidas sobre Prevención del Delito y Tratamiento del Delincuente, celebrado en la Habana (Cuba), del 27-8-1990 al 7-9-1990 (UN Doc. A/CONF.144/28/Rev.1 at 189-1990); par. 24.a) de "Recomendación REC" (2000), adoptada por el Comité de Ministros el 6-10-2000 en la 724 a reunión de Ministros; y el par. 3.c) de "Normas de Responsabilidad Profesional y Declaración de Derechos y Deberes Fundamentales de los Fiscales adoptadas por la Asociación Internacional de Fiscales" (IAP) el 23-4-1999 en Asociación Internacional de Fiscales (2009). Manual de Derechos Humanos para fiscales. $1^{\mathrm{a}}$ ed. en español. Buenos Aires. MPF CABA.

40 En este caso, el art. 273 del CPPF establece que el juez debe absolver si los acusadores así lo requirieran. Conviene destacar que de la hermenéutica efectuada por la CSJN en "Tarifeño", "Mostaccio" y "Agüero" podía inferirse el carácter vinculante para el juzgador de la decisión del fiscal de no acusar al final del debate. Sin embargo, Carrió expresa serias dudas sobre la existencia de una transgresión constitucional cuando se dicta una condena en este contexto, aunque afirma que pareciera reñir con el proceso acusatorio [cfr. Carrió, A. D. (2015). Garantías Constitucionales en el proceso penal. $6^{\mathrm{a}}$ ed. Buenos Aires. Hammurabi, 88].

41 Maier, J. B. J. Derecho Procesal Penal, II... Ob. cit., 322-323.

42 Ibídem, 323.

43 Ídem. 
De hecho, Maier pareciera enseñarse remiso a aceptar esta postura, al concluir que "[d]e allí a sostener, por esta misma razón, que la fiscalía no cumple la función material de una parte del procedimiento, sino que, antes bien, solo formalmente está puesto en esa condición, para facilitar la defensa del imputado, que, por ello el proceso penal no es un proceso de partes, a semejanza de otros procedimientos judiciales, y, por fin, que la fiscalía no cumple el papel material de un acusador, no hay ni siquiera un trecho [...]"44.

En consecuencia, el jurista plantea que, tal vez, antagónicamente a la posición dominante debería afirmarse que el principio de legalidad procesal sería producto más o menos aproximado a la idea política "que apoya la justicia de la solución, del fallo, en base a la verdad (correspondencia) histórica, concebida como ideal del procedimiento penal o de la actuación de la ley penal" 45 , pues "[j]usticia y verdad son [...], para nuestra cultura jurídica, conceptos implicados mutuamente, aunque no coincidan en su contenido" 46 .

Dado lo expuesto, amerita despejar aparentes contradicciones que pueden anidarse en el lector entre la posición estratégica de los fiscales en un proceso de partes como el acusatorio; y esa manda de colocar todos los medios al alcance a fin de ajustar la actuación del MPF a la verdad de las cosas (deber de objetividad).

Una buena llave para resolver esta relación, en apariencia agonal, la ofrece Luis A. Arnaudo, a través de un correcto distingo entre la objetividad del fiscal y la imparcialidad del juez. Explica, el magistrado, que se alude a objetividad, por cuanto el MPF "no interviene en el proceso penal en virtud de ningún interés subjetivo, lo cual lo diferencia drásticamente de la posición que normalmente tienen las restantes partes, que actúan en representación de algún sujeto en particular: del imputado, en el caso del Ministerio Público de la Defensa, o del menor de edad o del insano, en el caso del Ministerio Público Tutelar"47.

Añade, el citado, que si bien no resulta del todo errado relacionar la objetividad a la imparcialidad (en tanto, difícilmente pueda suponerse una actuación imparcial y, a la vez, no objetiva), ciertamente ambos conceptos responden a posiciones diversas en el proceso ${ }^{48}$.

Nótese que las palabras "imparcial" e "imparcialidad" refieren a quien "1. adj. [...] juzga o procede con imparcialidad. Juez imparcial. U. t. c. s. 2. adj. Que incluye o denota imparcialidad. Historia imparcial. 3. adj. Que no

44 Ídem.

45 Ídem.

46 Ídem.

47 Arnaudo, L. A. (2017). "Comentario a arts. $3^{\circ} / 9^{\circ}$ del CPPCABA". En AA. VV. Código Procesal Penal de la Ciudad Autónoma de Buenos Aires. T. 1. Buenos Aires. Hammurabi, 79. 48 Ídem. 
se adhiere a ningún partido o no entra en ninguna parcialidad. U. t. c." ${ }^{49} ;$ y la "1. f. Falta de designio anticipado o de prevención en favor o en contra de alguien o algo, que permite juzgar o proceder con rectitud"50.

De hecho, esa inexistencia de intereses, designios anticipados o ideas preconcebidas en quienes deben resolver el fondo de la cuestión, en pos de garantizar la imparcialidad, traduce una neutralidad que no solo responde a un rol del sujeto procesal en el escenario contradictorio, sino también se conjuga con una faz temporal, pues como afirma Arnaudo: "[...] el fiscal trabaja a partir de hipótesis, construyendo una imputación a futuro, si es que consigue elementos para hacerlo, mientras que el juez -imparcial- toma conocimiento de aquella posición, la analiza y decide, de manera que su juicio es posterior [...] Esa posición ex post es una de las bases fundamentales, sino la más relevante, entre la distinción entre el rol del fiscal y el juez, entre la objetividad y la imparcialidad. Es lo que lleva a diseñar [...] un sistema acusatorio en el que los jueces toman sus decisiones mayormente tras audiencias [...] De tal modo, la distinción [...] está dada, fundamentalmente, por el abordaje del sujeto procesal, conforme a su rol. Si es fiscal, deberá ser objetivo, pero su propia función importa excluir la adjetivación de imparcial, pues su tarea requirente lo coloca en la posición de parte"51.

\section{2.f. Necesidad de garantizar el criterio de objetividad}

Ha de remarcarse que explorar la verdad es un axioma esencial en toda propuesta de administrar una auténtica justicia acorde a la realidad. En efecto, esta manda irrenunciable es una garantía del imputado y de la víctima (comunidad política o particular).

Cabe interrogarse, entonces, si no podrían trasvasarse ciertas nociones ligadas a la imparcialidad ${ }^{52}$ a la objetividad del fiscal, aunque la primera

49 Real Academia Española (RAE). Diccionario de la Real Academia Española (disponible en https://dle.rae.es/imparcial?m=form, fecha de consulta: 11-12-2020). Ed. del Tricentenario, actualización 2020 .

50 Real Academia Española (RAE). Diccionario de la Real Academia Española (disponible en https://dle.rae.es/imparcialidad?m=form, fecha de consulta: 11-12-2020). Ed. del Tricentenario, actualización 2020.

51 Arnaudo, L. A. Ob. cit., 79-80.

52 No puede obviarse, que según lo sentado por la Corte Suprema de Justicia (cfr. Fallos: 327:5863 y Fallos: 328:1491), la imparcialidad debe considerarse desde dos prismas: uno objetivo y otro subjetivo. La primera de estas dos facetas de la imparcialidad se vincula a actos objetivos del procedimiento desarrollados por el juez con independencia de su personalidad, honorabilidad o labor particular; en tanto la segunda alude a actitudes o intereses específicos del órgano juzgador respecto a la manera de resolver la causa. 
y la segunda no impliquen exactamente lo mismo, pues este deber conlleva aneja la necesidad no solo de que el representante del MPF no presente un interés individual en el caso; sino también disipar cualquier duda pasible de generarse respecto al carácter objetivo de su actuación.

Todavía más, esto debe resignificarse a la luz de lo planteado por Gössel, cuando el doctrinario esgrime que con “la 'decisión' adoptada acerca del sobreseimiento o la acusación, el Ministerio Fiscal no se limita ya a ejercer una mera función de control de la actividad de determinados órganos estatales, sino que efectivamente resuelve, en este momento el proceso penal, con facultad propia, sobre la continuación del proceso o el sobreseimiento de la causa"53.

Esta aserción interpela a preguntarse: ¿qué órgano externo controla a este MPF?; por cuanto, como asevera el Profesor alemán, "[d]esde un punto de vista objetivo, huelga todo temor, pues es de presuponer que el Ministerio Fiscal no tiene ningún interés personal en acusaciones innecesarias, que en todo caso van a llegar a una absolución en el momento de la aplicación jurisdiccional de la legislación penal" 54 . En efecto, "[a]ntes bien, los intereses funcionales a la prestación del servicio propician que el Ministerio Fiscal se mantenga objetivo, ante la hipotética sospecha de la comisión de un delito"; pero en "todo caso han de establecerse las garantías necesarias contra decisiones arbitrarias del Ministerio Fiscal, en especial, las referidas a la omisión de interponer la acusación"55.

Es que como bien advierte el doctrinario aludido, esta decisión adoptada por los fiscales con facultad propia (ya sea la de no iniciar la persecución penal, la de sobreseer o la de no acusar) no se limita al ejercicio de una mera función de contralor de la tarea desarrollada por determinados órganos estatales, sino que, concretamente, resuelve en esta instancia si la investigación penal se iniciará, proseguirá o si su suerte será sellada con un archivo o sobreseimiento ${ }^{56}$.

Más aún, este interrogante adquiere hoy inusitado vigor, frente a la recepción en los códigos procesales y el Código Penal de la Nación ${ }^{57}$, de un principio de oportunidad que tiende a distender al principio de legalidad procesal, es decir, aquel "deber del Ministerio Público Fiscal de ejercer de oficio la acción penal ante la noticia de la comisión de un delito de acción

53 Gössel, K. H. Ob. cit., 48.

54 Ibídem. T. I, 49.

55 Ibídem, 49.

56 Pueden trazarse analogías con lo afirmado en Gössel, K. H. Ob. cit. T. I, 48.

57 Cfr. arts. 59 y 71 del Código Penal. 
pública, y no suspender, interrumpir o desistir de la persecución, salvo en las excepciones expresamente determinadas por la ley"58.

La relevancia de resguardar esa objetividad en el órgano acusador se vuelve de hecho más patente, ante la incursión de un instituto de la insignificancia procesal ${ }^{59}$, que permite introducir el "principio de oportunidad libre", pero con el ropaje de una "oportunidad reglada"60.

Es que "los conceptos indeterminados implícitos a la insignificancia procesal ofrecen terreno fértil para que, so pretexto de razones pragmáticas o político-criminales, los fiscales decidan si impulsan o no la acción penal de manera arbitraria en estadios iniciales del proceso, caracterizados por una ausencia de visibilidad"61.

De hecho, la abstracción y vaguedad de las fórmulas utilizadas para justificar este instituto (ej.: necesidades político-criminales, mero pragmatismo y, fundamentalmente, el baremo "hecho de menor significación" o que no afecta "gravemente el interés público"62) denotan los peligros de la textura abierta de un lenguaje particularmente apto para trocar la "discrecionalidad del fiscal" en "arbitrariedad del órgano persecutor".

Por lo pronto, es elemental notar que si la determinación de cuándo el interés público se encuentra comprometido o si el hecho cometido reviste importancia depende de una valoración subjetiva de cada fiscal, desligada de vinculaciones externas y delimitada por relativas ponderaciones políticocriminales signadas por una imprecisa eficiencia, no solo los principios de igualdad ante la ley (art. 16 de la $\mathrm{CN})^{63}$, legalidad material y previsibilidad resultan ajados ${ }^{64}$, sino también el mismo principio de objetividad.

58 Romero Berdullas, C. M. (2020). Criterios de oportunidad en el proceso penal. Buenos Aires. Hammurabi, 17.

59 La insignificancia procesal se halla regulada en los arts. 30 y 31 del CPPF y los Códigos Procesales Penales de la Ciudad Autónoma Buenos Aires (art. 212, CPPCABA); provincia de Buenos Aires (art. 56 bis, CPP); la Pampa (art. 15, inc. $1^{\circ}$, CPP); la Rioja (art. 204 bis, inc. $1^{\circ}$, CPP); Río Negro (art. 180 ter, inc. $1^{\circ}$, CPP); Santa Fe (art. 19, CPP); Mendoza (art. 26, CPP); Chubut (art. 44, CPP), el Chaco (art. $6^{\circ}$ bis, inc. $1^{\circ}$, CPP); Entre Ríos (art. $5^{\circ}$, CPP); Jujuy (art. 101 , inc. $1^{\circ}, \mathrm{CPP}$ ); Neuquén (art. 106, inc. $1^{\circ}, \mathrm{CPP}$ ); Misiones (art. 60, inc. b, CPP) y Santiago del Estero (art. $\left.2^{\circ}, \mathrm{CPP}\right)$.

60 Cfr. in extenso Romero Berdullas, C. M. (2020). Derecho Penal Líquido. Inconstitucionalidad del principio de oportunidad. Buenos Aires. Ad-Hoc; y Romero Berdullas, C. M. Criterios de oportunidad en el proceso penal. Ob. cit.

61 Romero Berdullas, C. M. Criterios de oportunidad... Ob. cit., 128.

$62 \mathrm{El}$ art. 31 del CPPF faculta al fiscal a disponer de la acción penal pública si se tratase de hechos que, por su insignificancia, no afectasen gravemente el interés público.

63 En efecto, los conceptos indeterminados propenderían a que ante un mismo caso dos fiscales adoptaran criterios diversos y suministraran respuestas diferentes.

64 Romero Berdullas, C. M., Derecho Penal Líquido... Ob. cit., 363-364. 
Cabe señalar, además, "que el encumbramiento del fiscal con la facultad de adoptar un temperamento no persecutorio ante la comisión de un hecho en apariencia delictivo, en base a sus subjetivas valoraciones políticocriminales y los indeterminados conceptos" 65 inherentes a la insignificancia procesal ${ }^{66}$, o el principio de oportunidad libre, no solo "contradice la decisión adoptada al tipificarse ese hecho como delito de acción pública, por cuanto precisamente la gravedad de tales actos motivó al legislador a introducirlos en el Código Penal mediante la ley"67, sino también se vuelve agonal con ese deber de objetividad, en tanto el desarrollo de la persecución penal se hallará signado por la subjetividad de cada individuo o fiscal. Y como lo subjetivo es aquello "perteneciente o relativo al sujeto, considerado en oposición al mundo externo" y "al objeto en sí mismo"68; luego cabe inferir una indisimulable tensión entre el encomiado deber de objetividad y una persecución penal regida por la oportunidad libre o insignificancia procesal.

Se suman a esto otros escollos a la hora de conjugar esta insignificancia procesal, con una objetividad que puede resultar horadada frente a la ausencia de controles republicanos, sobre decisiones susceptibles de traducirse en la orfandad de persecución penal.

No puede soslayarse, en este sentido, que tal como lo explica la Corte Suprema en "Quiroga"69, el fiscal no puede ser imperado a desarrollar la persecución penal o acusación por el Poder Ejecutivo y Legislativo o los jueces, a fin de preservar la independencia de poderes, la autonomía del MPF e imparcialidad del órgano juzgador. De modo que, únicamente, se contempla la ocasional posibilidad de revisión de estas decisiones desestimatorias, a través de la actuación de un fiscal superior del mismo $\mathrm{MPF}^{70}$, cuya organización vertical y monocrática es conducida por autoridades caracterizadas

65 Ibídem, 401-402.

66 Debe distinguirse la insignificancia material de la procesal, pues la primera es un concepto relativo que responde a razones político-criminales de relocalización o de eficiencia orientadas a racionalizar la capacidad operativa del MPF, de modo tal de otorgar prevalencia a la persecución de hechos socialmente más cuantificables [Binder, A. M. (2014). Derecho Procesal Penal. T. II. Buenos Aires. Ad Hoc, 436-437 y Binder, A. M. (2009). Introducción al Derecho Procesal Penal. $2^{\mathrm{a}}$ ed. Buenos Aires. Ad Hoc, 221]. Contrariamente, la segunda deriva de la máxima "el tribunal no trata con pequeñeces", pragmática preconizada por Roxin [Roxin, C. (1997). Derecho Penal -Parte General-. T. I. Madrid. Civitas, pp. 292-296], y encuentra asidero en la aplicación de categorías, a partir de las cuales se considera atípicas nimias afectaciones de bienes jurídicos.

67 Romero Berdullas, C. M. Derecho Penal Líquido... Ob. cit., 401-402.

68 Real Academia Española (RAE). Diccionario de la Real Academia Española (disponible en https://dle.rae.es/subjetivo?m=form, fecha de consulta: 17-12-2020). Ed. del Tricentenario, actualización 2020 .

69 Fallos: 327:5863.

70 Cfr. arts. 32, 33; 79, inc. j; 218 y 219 del CPPF. 
con la peculiar nota de no emanar del sufragio de la románticamente llamada soberanía popular (que como bien explican Bidart Campos ${ }^{71}$ y Castaño ${ }^{72}$ en realidad, es un mito).

En estos casos, si bien es otro sujeto quien puede ejercer el control (léase un fiscal jerárquicamente superior), si la víctima solicitó una revisión, nos hallamos igualmente ante un contralor endogámico dentro de un organismo monocrático, jerárquico y guiado por la unidad e indivisibilidad de oficio, en donde el fiscal general puede dictar instrucciones generales o particulares, que deben ser observadas por los fiscales; e, incluso, reemplazar a un funcionario inferior por otro (facultad de sustitución) o atraer hacia sí el asunto (facultad de devolución).

Por ende, no sería afortunado trazar una equiparación entre este contralor endógeno y el realizado mediante la interposición de los recursos por el tribunal ad quem respecto a lo decidido por el tribunal a quo, por cuanto el esquema organizativo del MPF difiere de las reglas que gobiernan por principio a los jueces, su ideal de distribución de competencia legal y la independencia con la cual ejercen sus funciones en una organización fundamentalmente horizontal ${ }^{73}$.

Por consiguiente, si pasamos la criba sobre esta posible revisión desde una perspectiva realista, esto es, una mirada que considere esa propia defectuosidad de todo hombre, "su posible corrupción y las posibilidades de que los abusos se incrementen cuando los sujetos de un mismo organismo son quienes deciden si impulsan o no la acción, además de ejercer el contralor de estas decisiones"74; luego no podemos obviar la importancia de cauterizar una potencial mengua del criterio de objetividad en los fiscales.

Si partimos de una auténtica mirada realista y racional no podemos esquivar ciertos interrogantes, tales como: ¿si no podría configurarse una hipotética venalidad en la función, un tráfico de influencias, un factible cohecho, o una complicidad entre, por ejemplo, fiscales de una misma zona con sus superiores jerárquicos para no ejercer la acción penal en determinados supuestos; o un fiscal en el cual converjan todas las investigaciones sobre una determinada clase de delitos (ej.: fiscalías especializadas) y personal de las fuerzas de seguridad, representantes de otros poderes u operadores

71 Cfr. Bidart Campos, G. J. (2005). Lecciones Elementales de Política. Buenos Aires. Ediar, 236-237.

72 Castaño, S. R. (2014). La realidad del poder constituyente, entre el mito liberal y el cuestionamiento contrarrevolucionario. Cuadernos del Instituto Filosófico de Balmesiana, Año 63, Nº 147, enero-junio, Espíritu, España, 141-169.

73 Romero Berdullas, C. M. Derecho Penal Líquido... Ob. cit., 253.

74 Ibídem, 253-254. 
judiciales?; y ¿cómo funcionarían los controles internos ante estas circunstancias u otras, si es que se efectivizara esa revisión? ${ }^{75}$.

Incluso, vale preguntarse si no es necesario garantizar el deber de objetividad, frente a un principio de oportunidad que puede tornarse instrumental a la denominada "cifra dorada" de los delitos. Es que la nimia visibilidad de decisiones adoptadas señeramente por los fiscales en etapas precoces de las investigaciones y sin controles republicanos idóneos, de consuno a la ampliación del margen de una factible arbitrariedad del fiscal, propiciada mediante una insignificancia procesal consagrada a través de fórmulas abstractas, despierta una razonable inquietud respecto a las posibilidades de privilegiar, así, con un trato disímil a determinados imputados por motivos de venalidad en la función, tráfico de influencias y dádivas o prebendas económicas.

En consecuencia, la trascendencia de robustecer este deber de objetividad es revitalizada aún más ante esta apertura al principio de oportunidad, ya que al reemplazarse "el firme control intrínseco a un principio de legalidad procesal (que imperaba al fiscal a perseguir todos los hechos penales) por un autocontrol de una misma sección de poder, inexorablemente se lesionan el paradigma de no autocontrol y el sistema de frenos-contrapesos, ambos axiomas rubricados en las constituciones modernas" 76 .

Por cierto, como ya se ha demostrado en Derecho Penal Líquido. Inconstitucionalidad del principio de oportunidad, "si un arquetipo republicano reposa necesariamente sobre modelos tendentes a evitar el autocontrol, en el Derecho Penal moderno pareciera excluirse la posibilidad de concentrar en un solo organismo público (ej.: Ministerio Público Fiscal) el ejercicio del poder de persecución penal, junto al control de ese ejercicio"77.

Añádase que, de lesionarse bienes jurídicos difusos a través de ciertas conductas delictivas, probablemente la reacción del todo social se traduzca en pasividad o dispersión a la hora de solicitar la revisión de los archivos dispuestos por aplicación del llamado principio de oportunidad, aspecto tal vez susceptible de subsanarse por intermedio de revisiones automáticas dentro del MPF; pero sin sortear el antirrepublicano autocontrol ejercido por una misma sección de poder.

Tampoco puede obviarse que las posibilidades de una retracción de las revisiones de archivos dispuestos por los fiscales ante delitos tendentes a vulnerar bienes concretos pueden potenciarse, en tanto esta clase de decisiones basadas en la insignificancia procesal, mediante las cuales en

75 Ídem.

76 Romero Berdullas, C. M. Derecho Penal Líquido... Ob. cit., 388.

77 Ibídem, 253. 
definitiva se expresa a las víctimas que "por la naturaleza e importancia del hecho no se justifica la persecución"78, pueden ocasionar una razonable merma de confianza en el sistema de justicia; e, incluso, una indeseada revictimización.

Efectivamente, este tipo de respuestas suelen conducir a una crisis de fe en el Poder Judicial y a generar inseguridad en las víctimas, quienes no padecen solo "hechos graves", sino estrictamente "delitos", es decir, los acontecimientos más antijurídicos, cuya tipificación penal precisamente responde a la especial nocividad de esas conductas para la comunidad, tanto es así, que de no prohibirse esos actos sumamente perniciosos la ciudad no podría conservarse ${ }^{79}$.

De ahí la significancia de garantizar ese criterio de objetividad en el fiscal y reducir cualquier espacio posibilitador de un desempeño arbitrario del titular del ejercicio de la acción penal, en desmedro de la tranquilidad gnoseológica de las víctimas, quienes deben gozar de la seguridad psicológica de que dado el delito no imperará la impunidad.

Si bien la creación del cargo de defensor público de la víctima en la órbita de la Defensoría General de la Nación ${ }^{80}$ intenta superar esta cuestión, no alcanza el designio propuesto, por cuanto ese control exógeno, al circunscribir su actuación al patrocinio de las víctimas en razón de su especial vulnerabilidad, precariedad económica y/o gravedad de los hechos, no resulta suficiente; en tanto ningún otro organismo efectiviza un contralor similar y externo respecto al interés público de la comunidad política en la persecución de los delitos, como sí lo haría naturalmente el fiscal a través del principio de legalidad procesal.

Y esto último es de suma importancia destacarlo, en la medida en que, como enseña el Aquinate, ante la perpetración de un delito, no sólo se hiere a la persona singular (o parte ordenada al todo) en su bien, sino también de modo prevalente se lesiona a toda la comunidad política ${ }^{81}$. Pues tal cual lo explica el Dr. Alfredo L. Repetto, frente a la consumación de un hecho penal, se incumplen dos deberes: a) uno de justicia conmutativa, que impera a respetar la relación del titular del bien jurídico con su bien; junto a b) otro de justicia general o legal, expresado en el imperativo de no perturbar los de-

78 Art. 212 del CPPCABA.

79 Cfr. Santo Tomás de Aquino (1998). Suma de Teología. $3^{\mathrm{a}}$ ed. Madrid. BAC, I-II, q. 96, a. 2 ; y II-II, q. 77, a. 1 , resp. a obj. 1 . V y VI).

80 Mediante la promulgación de la Ley $\mathrm{N}^{\circ} 27.372$ (cf. arts. $5^{\circ}$, inc. m; $21 ; 15 ; 17$; capítulos

81 Santo Tomás de Aquino. Suma de Teología, I-II, q. 21, a. 3. 
rechos personales de los demás y respetar la vida pacífica, que se encuentra incardinado en el fin de conservar el bien común ${ }^{82}$.

Por ello, ya se ha dicho que en "el cumplimiento de la ley penal el principal interesado es el Estado, dado que el fin del Derecho Penal es en lo inmediato el bien de una víctima particular (o sea, restablecer la igualdad de justicia particular quebrantada), pero también su finalidad inmediata o mediata (según cuál sea el delito cometido) será siempre el bien común político, por cuanto en todo delito de acción pública existe una afectación prevalente de la víctima comunidad política"83.

De modo que no debe menospreciarse la lesión del orden de convivencia y la afectación de un bien común político, ambos ineludiblemente comprometidos en la perpetración de todo delito de acción pública. Pues no puede obviarse que, de existir una víctima particular inmediata de un delito, ésta es parte de una víctima comunidad política (todo) ${ }^{84}$, siempre herida frente a la comisión de una conducta delictiva, ya sea mediata o inmediatamente ${ }^{85}$.

\section{2.g. La garantía de objetividad}

Ante este contexto, cabría interrogarse si no deberían arbitrarse medidas conducentes para asegurar en cada fiscal una objetividad no sólo "de hecho", sino también "aparente", independientemente de la incólume organización piramidal y jerárquica del MPF, la cual, como es sabido, se encuentra regida por un principio de unidad de actuación, cuyos orígenes se remontan al año 1302, data en la cual Felipe "el hermoso" erigiría en Francia a los

82 Cfr. Repetto, A. (2007). "La importancia del Derecho y del Derecho Penal”. En Diario de Política Criminal, $\mathrm{n}^{\circ}$ 11.780. Buenos Aires. El Derecho, acápite 3.4.

83 Romero Berdullas, C. M. (2019). "De los delitos y los conflictos". Prudentia Iuris, n ${ }^{\circ}$ 88. Buenos Aires. Educa, 27.

84 Vale recordar, que cuando uno "[...] hiere una mano, consiguientemente hiere al hombre. Luego, cuando uno obra para bien o para mal de otra persona singular, le corresponde de dos modos razón de mérito o de demérito. Uno, porque le debe retribuir la persona singular a la que ayuda u ofende. Otro, porque le debe retribución todo el colectivo. Además, cuando uno ordena su acto directamente para bien o para mal de todo el colectivo, le debe retribución primero y principalmente todo el colectivo, en efecto, pero secundariamente todas las partes del colectivo" (Santo Tomás de Aquino. Suma de Teología, I-II, q. 21, a. 3).

85 Por ejemplo, si el consumado es un delito contra la seguridad pública, claramente se advierte que es la comunidad política la víctima inmediata del hecho penal. Por el contrario, si el delito cometido es el homicidio prenatal o aborto, la víctima inmediata es el niño por nacer a la cual se le dio muerte, pero el Estado o comunidad política es víctima mediata. Para mayor ilustración, cfr. Romero Berdullas, C. M. De los delitos ... Ob. cit., 27-28. 
procuradores generales del rey (procurers $d u$ roi) en calidad de guardianes de los intereses de la corona ${ }^{86}$.

En oportunidad de analizar esto, ya se ha expresado: "[...] el fiscal no sólo debe ser objetivo, sino que además debe parecerlo, pues esta objetividad se halla estrechamente ligada a la independencia del director de la investigación en esa custodia de los derechos y garantías consagrados en la Constitución Política. De ahí la importancia de establecer buenas prácticas destinadas a neutralizar cualquier viso de asignación arbitraria de un fiscal para que investigue un delito con posterioridad al hecho del proceso, pues las especiales designaciones podrían despertar al menos una duda en el todo social, sobre si esa objetividad no es puesta en jaque ante factibles presiones, influencias e interferencias en la autonomía funcional, dirigidas en perjuicio o privilegio de un caso particular"87.

Avala más esta tesitura, el hecho de que amén del posible resguardo garantizado al imputado por el juez de garantías sobre persecuciones arbitrarias, cualquier paradigma regido por la insignificancia procesal o la oportunidad libre entraña el peligro de poner en crisis esa objetividad ineludible en detrimento de la víctima comunidad política, la víctima particular y el bien común.

Un riesgo que además se ve incrementado, cuando es el mismo MPF el encargado de controlar ocasionalmente la decisión de no iniciar la acción penal ante la noticia criminal o archivar el caso en base a conceptos indeterminados que cuanto menos orillan con el subjetivismo de cada cual, en tanto este método de contralor no se ajusta a un adecuado sistema de frenos y contrapesos, ni al paradigma de no autocontrol de una misma sección, ambos baluartes constitucionales afincados en una concepción de un ejercicio equilibrado del poder, ya enseñada desde antaño por la tradición ${ }^{88}$ en miras de sofrenar potenciales abusos.

86 Los procuradores del rey integraban y administraban el parquet, de modo que participaban de la dignidad real. En esta institución podemos rastrear los orígenes de la unidad de actuación de sus miembros, ya que el dictamen o la conclusión de cualquiera de sus integrantes eran emitidos en nombre del parquet. Más aún, tal era la uniformidad de acción de estos funcionarios, que las reglas de cortesía compartían idéntica impronta. Tanto es así, que a modo de ej., si en una audiencia se incorporaba uno de sus agentes el resto se ponía en pie, en tanto en la Corte los magistrados del parquet se adelantaban y al son de "Sire, ce sont vos gens", saludaban al unísono a su rey [cfr. Ayarragaray, C. (1928). El Ministerio Público. Buenos Aires. J. Lajouane \& Cía. Editores, 44-46].

87 Romero Berdullas, C. M. (2015). “\#Proceso Acusatorio...”. En ob. cit., 57-110.

88 Cfr. Aristóteles (2014). Política. Buenos Aires. Alianza; Cicerón, M. T. (1982). "Sobre la República". En Obras Políticas. Madrid. Gredos; y Santo Tomás de Aquino (2016). El Gobernante Cristiano (De regímene principum ad regem Cypri). Córdoba. Athanasius. 
Lo explicado conlleva a preguntarse si no debería constituirse una suerte de garantía análoga a la del juez natural respecto al marco de actuación del fiscal, a fin de asegurar esa objetividad de hecho y aparente no solo frente al imputado, sino también frente a las víctimas.

Vale interrogarse, si no deberían proyectarse ciertos contenidos de esa garantía del juez natural, que según el Tribunal cimero propende a garantizar una justicia imparcial e independiente ${ }^{89}$, hacia una persecución penal preservada de cualquier designación directa, disimulada o encubierta con posterioridad al hecho de la causa del fiscal a cargo de la pesquisa.

Como explica Bidart Campos, la garantía del "juez natural" acogida en el art. 18 de la Constitución Nacional expresa que "para cada causa o proceso judicial 'su' juez natural es el tribunal judicial cuya creación, jurisdicción y competencia provienen de una ley anterior al 'hecho' que da origen a aquella causa (o proceso)" 90 .

Así, pues, la "cláusula constitucional [...] cubre los dos orígenes que puede tener su afectación porque, además de asegurar que nadie debe ser sacado de los jueces designados por la ley antes del hecho de la causa, proscribe los tribunales creados para la ocasión (ver arts. $8^{\circ}, \mathrm{CADH}, \mathrm{XXVI}$, DADDH, 10, DUDH y 14.1, PIDCP)"91. De esta manera, la Constitución Nacional procura clausurar toda chance de que los órganos de gobierno supriman o determinen del tribunal competente para el caso ${ }^{92}$.

Si bien la "garantía del juez natural" se encuentra expresamente consagrada en la Constitución Nacional" ${ }^{93}$, es posible afirmar que la "garantía de objetividad del fiscal" se encuentra implícitamente afirmada en la manda constitucional de "promover la actuación de la justicia en defensa de la legalidad de los intereses generales de la sociedad" (art. 120, CN) ${ }^{94}$; y la meta de procurar un "dar a cada uno lo suyo" acorde a la realidad.

89 Fallos: 234:482, "Grisolía, Francisco Mariano", 1956; y Fallos: 338:601, "Meynet, Álvaro Javier", 2015.

90 Bidart Campos, G. J. (2004). Compendio de Derecho Constitucional. Buenos Aires. Ediar, 185.

91 D’Albora Francisco J. (2003). Código Procesal Penal de la Nación anotado, comentado $y$ concordado. $6^{\mathrm{a}}$ ed. Buenos Aires. Lexis Nexis - Abeledo Perrot, 2.

92 Maier, J. B. J. (2004). Derecho Procesal Penal, Fundamentos. $2^{\mathrm{a}}$ ed. Buenos Aires. Editorial del Puerto, 765.

93 En adelante, CN.

94 Fórmula replicada en el art. $1^{\circ}$ de la Ley $\mathrm{N}^{\circ} 27.148$ (Ley Orgánica del MPF de Nación) al definir la misión institucional, que reconduce a los principios funcionales contemplados en el art. $9^{\circ}$, donde el principio de objetividad es claramente receptado. Análogas prescripciones se observan en la Constitución de la CABA (art. 125, primer párr.) y en el art. $2^{\circ}$ de la Ley local $\mathrm{N}^{\circ}$ 1.903 (Ley Orgánica del MP porteño). 
Pues como ya se explicó, la objetividad y la verdad constituyen una garantía de las víctimas, al posibilitar la concreción de la manda de dar a quien delinque su pena y no al inocente (acto de justicia ordenado al bien común), pero además es un reaseguro de los imputados, en tanto ese "ser objetivo" se opone a las persecuciones signadas por la arbitrariedad.

Si tal cual retrata metafóricamente Roxin, el Derecho Procesal Penal es "el sismógrafo de la Constitución del Estado"95, es del todo lógico que la actuación del fiscal a lo largo de la persecución penal y el proceso se ajuste a todas las garantías estatuidas en la Constitución Política. Y aquí es clave resaltar la palabra "todas" cuando tratamos el deber de objetividad, pues es fundamental no recortar el auténtico significado de la palabra "garantía", término que refiere a aquella "cosa que asegura y protege contra algún riesgo o necesidad"; y la "seguridad o certeza que se tiene sobre algo"96.

Por ello es importante no concebir al deber de objetividad tan solo como una garantía individual del imputado ante posibles persecuciones arbitrarias (susceptibles de ser corregidas mediante la actuación del juez), sino que es esencial no obviar su trascendencia para concretar una garantía de justicia penal sobreentendida en la Constitución Nacional ${ }^{97}$, consagrada en su Preámbulo y expresada en los deberes de protección del Estado ${ }^{98}$, entre cuyos contenidos se encuentra la prescripción iusnatural de evidencia inmediata, de que dado el delito debe restaurarse penalmente el orden conculcado en procura de las "justas exigencia del bien común"99 de la víctima comunidad política.

Si partimos de una actitud realista no podemos menospreciar esa garantía de la ciudadanía y Derecho Subjetivo, de que dado el delito no prevalecerá la impunidad sobre el ius puniendi estatal. Por eso, es dirimente

95 Roxin, C. (2000). Derecho Procesal Penal. $1^{a}$ ed. Buenos Aires. Editores del Puerto, 10.

96 Cfr.las diferentes acepciones de la palabra garantía en el Diccionario de la Real Lengua Española.Disponible en http://lema.rae.es/drae2001/srv/search?id=ningOSAUIDXX2pK1oGwO (fecha de consulta: 23-3-2020).

97 Sobreentendida no solo desde una perspectiva realista clásica, sino también moderna, amén de partir de otros fundamentos y presupuestos, como por ej., la enseñada en Isensee, J. (2014). El Derecho Constitucional a la seguridad: sobre los deberes de protección del Estado constitucional liberal. Santa Fe. Rubinzal Culzoni, 17-22, 58 y 67.

98 Pueden entreverse dos obligaciones del Estado, una encaminada a respetar los derechos, garantías y libertades del hombre frente a la conducta estatal; y otra delimitada por exigencias concernientes a asegurar el libre y pleno goce de los Derechos Humanos (cfr. Corte Interamericana de Derechos Humanos en el Caso "Velásquez Rodríguez vs. Honduras", Sentencia de 29 de julio de 1988, parágrafos nros. 166 y 167). Por tanto, de esto puede deducirse la obligación del Estado de contener, refrenar y sancionar el delito con la mayor eficacia factible para garantizar la seguridad de los ciudadanos.

99 Cfr. "Alonso, Jorge F. y otros s/ contrabando de estupefacientes y otros delitos", causa $n^{\circ}$ 3161. A. 445. XXVIII. 26-12-1995, CSJN-Fallos: 318:2611. 
actualizar esa seguridad gnoseológica -redituable en tranquilidad psicológica de la sociedad-, a través de salvaguardas eficaces de esa "garantía de objetividad del fiscal" (de hecho y aparente) e idóneas para comunicar a las víctimas de las conductas delictivas (actuales o potenciales) la certeza de que la persecución y respuesta penal, dada su función pública encaminada al bien común político, se concretará a fin de alcanzar los legítimos fines de las penas ${ }^{100}$, ante la perpetración de ese grave mal denominado "delito".

Cobra entonces especial relieve, dar suficientes garantías al todo social, de que esa objetividad del fiscal, tan ensamblada a su independencia como director de la investigación, no resultará mancillada, tras la introducción de estas herramientas novedosas de disponibilidad de la acción penal, de por sí ajenas a nuestra rica tradición histórica. Particularmente, esto se ve resignificado frente al peligro de que arbitrariamente se disponga la no persecución penal o el archivo del caso en base a la oportunidad libre propiciada por la "insignificancia procesal", elemento potenciado incluso dada la factible defectuosidad del hombre y su posible corrupción.

En fin, esto evidencia el valor de ajustar la asignación de los casos a estándares que eliminen cualquier viso de asignación arbitraria de un fiscal para que investigue un delito con posterioridad al hecho del proceso, por cuanto las especiales designaciones podrían anidar una duda razonable en la víctima particular y/o víctima comunidad política, sobre si esa objetividad en el caso particular -la cual debería guiarse por la medida de lo real- no se encuentra viciada en beneficio o desmedro del imputado por efecto de la presión política, connivencia o influencia de un superior jerárquico.

Si bien la "garantía del juez natural" alude a leyes de competencia y aquí stricto sensu nos hallaríamos ante reglas de distribución de casos dentro de un mismo organismo conformado por magistrados igual de competentes, si tomamos como principio rector la "garantía del fiscal objetivo", se advierte la significancia de arbitrar medidas destinadas a disipar cualquier duda posible de generarse sobre esa objetividad llamada a ser preservada.

Naturalmente, estas acciones tendentes a evanecer cualquier duda susceptible de originarse en torno a una merma de objetividad del fiscal, no pueden perder de vista la necesidad de equilibrar esta exigencia con un rol institucional del MPF diverso al de los jueces, que además es desarrollado a través de una organización monocrática de carácter jerárquico, regida por

100 Si la comunidad política no logró prevenir el delito nace el deber de restaurar el orden jurídico conculcado mediante una justa retribución, de ahí que la obligatoriedad de la persecución penal en los delitos de acción pública finca en ese "afianzar la justicia" consagrado en el preámbulo de la CN; e ínsito en ésta, cuando se dispone la necesidad de dictar un Código Penal y aplicar la pena a quien delinquió luego de un debido proceso. Para mayor ilustración, puede verse en extenso Romero Berdullas, C. M. Derecho Penal Líquido... Ob. cit. 
un principio de unidad e indivisibilidad de oficio y una flexibilidad de sus estructuras indispensable, en vistas al logro de una mayor eficiencia frente al dinamismo de los disímiles fenómenos delictivos ${ }^{101}$.

En ese entendimiento, cabría analizar si no podrían establecerse métodos estandarizados de carácter aleatorio, orientados a: a) sortear la asignación de un asunto a través de una decisión individual luego del hecho del proceso, en aras de despejar cualquier sospecha de subjetividad en el fiscal; b) asegurar que la determinación del órgano encargado de la persecución no privilegia o perjudica un posible interés involucrado en la causa, y c) evitar el denominado "forum shopping", que se concreta cuando alguno de los protagonistas puede escoger al fiscal a cargo de la investigación, a partir de un conocimiento sobre el método de elección, susceptible de traducirse en un juicio predictivo acerca de la asignación del caso.

Siguiendo esta idea guía, una posibilidad viable es fijar una metodología orientada a asignar el caso ingresado al fiscal que presente en cada momento una menor carga laboral. Esto podría instrumentarse mediante un software que aplique un algoritmo, a través del cual se analicen diferentes variables del cúmulo y/o complejidad del caudal de trabajo de cada fiscal ${ }^{102}$, con el propósito de adjudicar dinámica y eficientemente los casos en pos de propiciar una respuesta dotada de la mayor celeridad posible; e incluso salvaguardar, así, la objetividad de cada representante del MPF ${ }^{103}$.

Debe advertirse sobre la necesidad de que ese método aleatorio de asignación de casos (flujo dinámico) no sea alterado o desvirtuado por una decisión particular de los superiores jerárquicos. De hecho, debería reverse esa facultad que las leyes orgánicas confieren a las máximas autoridades de los Ministerio Públicos Fiscales de adoptar esas clases de decisiones, pues podría abrirse el grifo hacia una manipulación subrepticia o velada, en este caso, por intermedio de la ley.

Por otra parte, de devenir necesario disponer la actuación conjunta o alternativa de dos o más integrantes del MPF, dada la importancia o complejidad de un caso o fenómeno delictivo ${ }^{104}$, sería recomendable aplicar el mismo proceso aleatorio, de modo tal de remover cualquier posible duda

101 Cfr. art. $9^{\circ}$ de la Ley No 27.148 (Ley Orgánica del MPF de Nación).

102 Tales, como por ej., la cantidad de casos ingresados, en trámite en cada fiscalía, su complejidad y la velocidad de respuesta de cada titular de la acción penal.

103 Experiencias de esta clase ya se han implementado otrora, tal como puede comprobarse con la lectura de Ministerio Público Fiscal de la CABA (2013). Nuevo diseño, fiscalías de la ciudad. Gamboa, A. (dirección); Romero Berdullas, C. M. (redacción); Peix, H. (redacción), 38; y Garavano, G. C. - Romero Berdullas, C. M. (2014). "El rol del Ministerio Público Fiscal de la CABA". En Derecho de la Ciudad de Buenos Aires. Buenos Aires. El Derecho, 214.

104 Cfr. arts 12, inc. d) de la Ley No 27.148 (Ley Orgánica del MPF de Nación) y art. 31, inc. $5^{\circ}$ de la Ley local No 1.903 (Ley Orgánica del MP de la CABA). 
sobre la objetividad de los magistrados asignados a la investigación; y establecer, además, como titular de la causa a quien primero fue designado para intervenir por el software implementado, en base al algoritmo dinámico del flujo de causas.

Asimismo, si la trascendencia pública o institucional, la complejidad de los hechos delictivos por investigar o motivos de política criminal requirieran la creación de unidades fiscales especializadas con el objeto de abordar con mayor eficacia determinadas materias ${ }^{105}$, sería aconsejable no concentrar en un único magistrado todos los casos ingresados sobre esas temáticas. No solo por posibles recusaciones o excusaciones, sino también para minimizar una posible lesión al principio de objetividad en la actuación fiscal, pues desde una perspectiva realista no puede obviarse la factible defectuosidad de todo hombre y las chances de que esta convergencia de poder tienda a potenciarse hasta decantar en abuso.

En estos supuestos de fiscalías especializadas pareciera más ajustado al canon de "objetividad de hecho y aparente", designar más de un magistrado con idoneidad específica sobre la materia; y aplicar el método aleatorio de asignación sobre estos casos, entre aquellos integrantes del MPF seleccionados por su versación particular.

\section{Conclusiones}

Hemos procurado poner de relieve la trascendencia de resignificar ese deber de objetividad del fiscal, tan íntimamente imbricado a una realidad de las cosas, que es presupuesto de la "justicia con el ser" aludida por Pieper; y solo puede darse en tanto los acusadores públicos presenten esa docilidad necesaria para dejarse determinar objetivamente por lo "que es".

También comprobamos que esa actitud cognoscitiva y ética de objetividad del fiscal intrínseca en la misión constitucional de "promover la actuación de la justicia en defensa de la legalidad de los intereses generales de la sociedad" (art. 120, CN) ${ }^{106}$ y el faro de procurar un "dar a cada uno lo suyo" acorde a la realidad, no solo constituye una garantía de los imputados ante persecuciones signadas por la arbitrariedad, sino también un reaseguro de las víctimas (comunidad política y particular) de los hechos penales, de que

105 Cfr. art. 32 de la Ley No 27.148 (Ley Orgánica del MPF de Nación).

106 Fórmula replicada en el art. $1^{\circ}$ de la Ley N² 27.148 (Ley Orgánica del MPF de Nación) al definir la misión institucional, que reconduce a los principios funcionales contemplados en el art. $9^{\circ}$, donde el principio de objetividad es claramente receptado. Análogas prescripciones contienen la Constitución de la CABA (art. 125, primer párr.) y el art. $2^{\circ}$ de la Ley local N ${ }^{\circ} 1.903$ (Ley Orgánica del MP porteño). 
dado ese mal gravísimo llamado "delito", la lesión al orden de justicia será restaurada en procura de las justas exigencias del bien común.

En definitiva, este trabajo pretendió plantear los riesgos corridos por esa preciada objetividad fiscal frente a cualquier escenario regido por conceptos indeterminados, tales como los ofrecidos por el principio de oportunidad libre o la insignificancia procesal, peligros que además resultan incrementados cuando el contralor de la decisión de no avanzar con la persecución penal no se adecúa al sistema de frenos y contrapesos, ni al paradigma de no autocontrol.

Este contexto, sumado a la posible defectuosidad de todo hombre (la cual no puede obviarse desde una mirada realista), interpelan a preservar esa garantía de objetividad en el fiscal y librarla en la mayor medida posible de todas las factibles presiones, influencias e interferencias en su autonomía funcional, que se dirijan en desmedro o privilegio de un caso particular.

Por consiguiente, la garantía del fiscal objetivo demanda la necesidad de disipar toda duda capaz de anidarse sobre cualquier designación directa o encubierta con posterioridad al hecho de la causa del acusador, pues frente a las novedades legislativas examinadas y una credibilidad del sistema de justicia hoy puesta en tela de juicio por la ciudadanía, las especiales designaciones podrían despertar al menos una inquietud razonable en el todo social, sobre una posible mengua de esa objetividad, que es una salvaguarda constitucional de la víctima comunidad política.

En el último tramo de este itinerario compartimos algunas directrices que pretenden acercarnos a una actuación fiscal más acorde a la garantía de "objetividad de hecho y aparente". Sin embargo, esta pieza únicamente aspira a abrir nuevas preguntas, debates y diálogos, que indefectiblemente deben darse en torno a las leyes ${ }^{107}$, como así también respecto al rol institucional de los Ministerios Públicos Fiscales ante las circunstancias del presente.

Claro que, para lograr ese cometido, un presupuesto insoslayable es el acontecer académico. Pues sin libertad filosófica y objetividad a la hora de contemplar al MPF, es improbable que logremos ajustar la actuación de este sujeto procesal a una realidad constitucional surcada por un sano equilibrio en el ejercicio del poder ${ }^{108}$. Inexorablemente, si no penetramos desinteresadamente en cuáles son las condiciones más adecuadas para potenciar la objetividad del fiscal, no solo no alcanzaremos efectos útiles para la conquista del bien común, sino que además el MPF no alcanzará esa madurez tan

107 Léase leyes de fondo, procesales y orgánicas de los Ministerios Públicos Fiscales.

108 Cfr. Pieper, J. (2003). El ocio y la vida intelectual. $8^{\mathrm{a}}$ ed. Madrid. Rialp, 184-187 y Pieper, J. (1984). “La libertad de la Theoria filosófica y sus contrarios”. En Antología. Barcelona. Herder, 132-138. 
deseada de cara a la comunidad política; y podría incluso trocar su estatus de adolescente tardío por el de analogado del cesarismo ${ }^{109}$.

\section{Bibliografía}

Aristóteles (2011). Ética Nicomáquea. Madrid, Gredos.

Aristóteles (2014). Política. Buenos Aires. Alianza.

Arnaudo, L. A. (2017). "Comentario a arts. 3\% $\% 9^{\circ}$ del CPPCABA". En AA. VV. Código Procesal Penal de la Ciudad Autónoma de Buenos Aires. T. 1. Buenos Aires. Hammurabi.

Asociación Internacional de Fiscales (2009). Manual de Derechos Humanos para fiscales. $1^{\mathrm{a}}$ ed. en español. Buenos Aires. MPF CABA.

Ayarragaray, C. (1928). El Ministerio Público. Buenos Aires. J. Lajouane \& Cía. Editores.

Bidart Campos, G. J. (2004). Compendio de Derecho Constitucional. Buenos Aires. Ediar.

Bidart Campos, G. J. (2005). Lecciones Elementales de Política. Buenos Aires. Ediar.

Binder, A. M. (2009). Introducción al Derecho Procesal Penal. $2^{\mathrm{a}}$ ed. Buenos Aires. Ad-Hoc.

Binder, A. M. (2014). Derecho Procesal Penal. T. II. Buenos Aires. Ad-Hoc.

Carrió, A. D. (2015). Garantías Constitucionales en el proceso penal. $6^{a}$ ed. Buenos Aires. Hammurabi.

Castaño, S. R. (2014). La realidad del poder constituyente, entre el mito liberal y el cuestionamiento contrarrevolucionario. España. Cuadernos del Instituto Filosófico de Balmesiana, Año 63, No 147, enero-junio, Espíritu.

Cicerón, M. T. (1982). "Sobre la República”. En Obras Políticas. Madrid. Gredos.

Corominas, J. (1981). Diccionario Crítico Etimológico Castellano e Hispánico. T. IV. Madrid. Gredos.

D’Albora F. J. (2003). Código Procesal Penal de la Nación anotado, comentado y concordado. $6^{\mathrm{a}}$ ed. Buenos Aires. Lexis Nexis - Abeledo Perrot.

Garavano, G. C. - Romero Berdullas, C. M. (2014). "El rol del Ministerio Público Fiscal de la CABA". En Derecho de la Ciudad de Buenos Aires. Buenos Aires. El Derecho.

Gössel, K. H. (2007). El Derecho Procesal Penal en el Estado de Derecho, Obras Completas. T. I. Buenos Aires. Rubinzal Culzoni.

Isensee, J. (2014). El Derecho Constitucional a la seguridad: sobre los deberes de protección del Estado constitucional liberal. Santa Fe. Rubinzal Culzoni.

Jiménez de Asúa, L. (1965). Tratado de Derecho Penal. El delito. T. III, $3^{\text {a }}$ ed. act. Buenos Aires. Losada.

109 Para mayor ilustración, véase Romero Berdullas, C. M. (2020). Derecho Penal Líquido. Ob. cit., 406-412. 


\section{LA GARANTÍA DE OBJETIVIDAD DEL FISCAL}

Lamas, F. A. (2013). El hombre y su conducta. Buenos Aires. Instituto de Estudios Filosóficos "Santo Tomás de Aquino".

Maier, J. B. J. (2003). “El Ministerio Público: ¿un adolescente?”. En AA. VV. El Ministerio Público en el Proceso Penal. $1^{\mathrm{a}}$ ed. Buenos Aires. Ad-Hoc.

Maier, J. B. J. (2004). Derecho Procesal Penal, Fundamentos. $2^{\text {a }}$ ed. Buenos Aires. Editorial del Puerto.

Maier, J. B. J. (2011). Derecho Procesal Penal, II. Parte General, Sujetos Procesales. $1^{\text {a }}$ ed., $2^{\text {a }}$ reimp. Buenos Aires. Editores del Puerto.

Ministerio Público Fiscal de la CABA (2013). Nuevo diseño, fiscalías de la ciudad. Gamboa, A. (dirección); Romero Berdullas, C. M. (redacción); Peix, H. (redacción).

Pieper, J. (1984). “La libertad de la Theoria filosófica y sus contrarios”. En Antología. Barcelona. Herder.

Pieper, J. (2003). El ocio y la vida intelectual. $8^{\mathrm{a}}$ ed. Madrid. Rialp.

Pieper, J. (2009). La Realidad y el Bien. La Verdad de las Cosas. Buenos Aires. Librería Córdoba.

Repetto, A. (2007). "La importancia del Derecho y del Derecho Penal". En Diario de Política Criminal, $\mathrm{n}^{\circ}$ 11.780. Buenos Aires. El Derecho.

Romero Berdullas, C. M. (2020). Criterios de oportunidad en el proceso penal. Buenos Aires. Hammurabi.

Romero Berdullas, C. M. (2019). "De los delitos y los conflictos". Prudentia Iuris, $\mathrm{n}^{\circ}$ 88. Buenos Aires. Educa.

Romero Berdullas, C. M. (2020). Derecho Penal Líquido. Inconstitucionalidad del principio de oportunidad. Buenos Aires. Ad-Hoc.

Romero Berdullas, C. M. (diciembre de 2018). "Mitos y realidades del proceso acusatorio". Prudentia Iuris $\mathrm{n}^{\circ} 86$. Buenos Aires. Educa.

Romero Berdullas, C. M. (2015). “\#Proceso Acusatorio: ¿Hashtag Constitucional?”. Forum 3. Buenos Aires. Educa.

Roxin, C. (1997). Derecho Penal -Parte General-. T. I. Madrid. Civitas.

Roxin, C. (2000). Derecho Procesal Penal. $1^{a}$ ed. Buenos Aires. Editores del Puerto.

Roxin, C. (2003). "Posición Jurídica y tareas futuras del Ministerio Público". En AA. VV. El Ministerio Público en el Proceso Penal. $1^{\text {a }}$ ed. Buenos Aires. Ad-Hoc.

Sacheri, C. (2016). Filosofía e Historia de las ideas filosóficas. Mendoza. Escipión.

Santo Tomás de Aquino (2016). El Gobernante Cristiano (De regímene principum ad regem Cypri). Córdoba. Athanasius.

Santo Tomás de Aquino (1998). Suma de Teología. $3^{a}$ ed. Madrid. BAC.

Vélez Mariconde, A. (1969). Derecho Procesal Penal. T. I. $2^{\text {a }}$ ed. Buenos Aires. Lerner. 